\title{
PENINGKATAN EFEKTIVITAS BELAJAR TOLAK PELURU MELALUI PENGGUNAAN MEDIA PELURU TIRUAN DARI BOLA PLASTIK PADA SISWA KELAS VI SEMESTER 1 SDN BABADAN DEMAK
}

\section{Mardiwon ${ }^{\bowtie}$}

SDN Babadan Bonang, Demak

Jawa Tengah, Indonesia

\section{Info Artikel}

Sejarah Artikel:

Diterima September 2016

Disetujui November 2016

Dipublikasikan Desember 2016

Keywords:

Effectiveness of Learning, Artificial Bullets, Media.

\begin{abstract}
This research is motivated less availability of instructional media shot put. So it needs to be replaced with another form of media-made bullets. The study design used is classroom action research. After carrying out repairs learning, student achievement is increasing both the first cycle and the second cycle. The results showed that (a) the activity of pre-cycle students by 50\%, the first cycle of $70 \%$, then the second cycle by $80 \%$ this means that there is an increase of $20 \%$ and $10 \% ;(B)$ the activities of teachers by $75 \%$ pre-cycle, the first cycle is $95 \%$, then the second cycle of 100\% means there is an increase of 20\% and 5\%; (C) The results of student learning prasiklus son reaches $59 \%$, the first cycle is $95 \%$, then the second cycle of $100 \%$; whereas female student learning outcomes pre-cycle reaches $41 \%$, the first cycle of $79 \%$, then the second cycle of 79\%; and whereas (d) Response (Level of Satisfaction Study) students, achieve student response rate of $85 \%$, has the following criteria Very Satisfied. This criterion illustrates that students really happy and really enjoyed the process of learning.
\end{abstract}

\begin{abstract}
Abstrak
Penelitian ini dilatarbelakangi kurang tersedianya media pembelajaran tolak peluru. Sehingga perlu diganti dengan media yang lain berupa peluru buatan. Desain penelitian yang dipakai adalah penelitian tindakan kelas. Setelah melaksanakan perbaikan pembelajaran, prestasi belajar siswa selalu meningkat baik siklus I maupun siklus II. Hasil penelitian menunjukkan bahwa (a) aktivitas siswa prasiklus sebesar 50\%, siklus pertama sebesar 70\%, kemudian pada siklus kedua sebesar $80 \%$ ini berarti ada peningkatan $20 \%$ dan $10 \%$; (b) aktivitas guru prasiklus sebesar $75 \%$, siklus pertama sebesar $95 \%$, kemudian pada siklus kedua sebesar $100 \%$ ini berarti ada peningkatan $20 \%$ dan 5\%; (c) Hasil belajar siswa putra prasiklus mencapai sebesar 59\%, siklus pertama sebesar 95\%, kemudian pada siklus kedua sebesar 100\%; sedangkan hasil belajar siswa putri prasiklus mencapai sebesar $41 \%$, siklus pertama sebesar $79 \%$, kemudian pada siklus kedua sebesar $79 \%$; dan sedangakn (d) Respon (Tingkat Kepuasan Belajar) Siswa, mencapai tingkat respon siswa sebesar 85\%, mempunyai kriteria Sangat Puas. Kriteria ini menggambarkan bahwa siswa betulbetul merasa senang dan sangat menikmati pembelajaranya.
\end{abstract}

(C) 2016 Universitas Muria Kudus

\footnotetext{
Alamat korespondensi:

Program Studi Pendidikan Guru Sekolah Dasar

Fakultas Keguruan dan Ilmu Pendidikan Universitas Muria Kudus

Kampus UMK Gondangmanis, Bae Kudus Gd. L. It I PO. BOX 53

Kudus

Tlp (0291) 438229 ex.147 Fax. (0291) 437198

E-mail: mardiwon@gmail.com
}

p-ISSN 2087-9385

e-ISSN 2528-696X 


\section{PENDAHULUAN}

Sarana prasarana merupakan salah satu bagian yang strategis dalam pencapaian tujuan pembelajaran. Dengan kata lain, lengkap dan tidak lengkapnya sarana prasarana pembelajaran turut mempengaruhi maksimal dan tidak maksimalnya ketercapaian tujuan pembelajaran. Sarana yang lengkap bisa memudahkan guru untuk mengejar target-target tertentu yang menjadi tujuan pembelajarannya. Begitu sebaliknya, sarana yang tidak lengkap akan menyulitkan bagi guru dalam mencapai targettarget tujuan pembelajarannya (Peraturan Menteri Pendidikan Nasional Republik Indonesia Nomor 24 tahun 2007).

Ini pula yang terjadi pada pembelajaran Tolak Peluru di SDN Babadan, Kondisi nyata di sekolah, media peluru hanya tersedia 2 buah, 1 peluru untuk putri dan 1 peluru untuk putra. Sementara rata-rata siswa di SDN Babadan berjumlah 40 - 45 orang, jadi komparasi antara jumlah peluru dan jumlah siswa adalah $1: 20$ putra/putri. Jelas dari gambaran tersebut bahwa proses pembelajaran Tolak Peluru menjadi tidak efektif, dan akibatnya bahwa target kurikulum menjadi sangat rendah.

Situasi dan kondisi ini sudah berjalan cukup lama dan sekolah sampai detik ini belum bisa memenuhi sarana peluru tersebut sampai batas yang cukup memadai atau kondisi ideal, misalnya dengan perbandingan $1: 2$ (1 peluru untuk 2 orang). Hal ini bisa dimengerti, karena sekolah mempunyai kebutuhan yang sangat banyak dan hampir semuanya mempunyai tingkat urgensitas yang tinggi untuk di penuhi oleh sekolah. Sehingga menuntut sekolah untuk menyediakan Peluru sesuai dengan kondisi ideal, merupakan suatu yang tidak realistis dan lebih jauhnya bisa menimbulkan gejolak dan iklim yang tidak kondusif di sekolah.

Oleh karena itu perlu sebuah pemecahan masalah yang sederhana dan bisa dilakukan oleh guru. Melihat permasalahan di atas, maka satu pemikiran yang muncul adalah bahwa perlu adanya sebuah media alternatif modifikatif/tiruan untuk mengganti peluru yang memang cukup mahal. Media alternatif tiruan tersebut harus bersifat bisa mewakili karakteristik peluru, murah, banyak tersedia atau mudah didapat. Salah satu alternatif pemecahan masalah ini adalah penggunaan media peluru tiruan dari bola plastik yang bisa meningkatkan efektivitas belajar tolak peluru di kelas VI SDN Babadan.

Dalam penelitian ini membahas kemampuan dan keefektifan dalam proses pembelajaran tolak peluru di kelas VI diantaranya aktivitas siswa kelas VI dalam belajar tolak peluru, aktivitas guru dalam mengajar tolak peluru, respon siswa terhadap pembelajaran tolak peluru dengan media peluru tiruan dari bola plastik, hasil belajar tolak peluru yang dilakukan siswa dengan media peluru tiruan dari bola plastik.

Tujuan dari penelitian tindakan kelas ini adalah untuk mengetahui apakah media peluru tiruan dari bola plastik bisa meningkatkan efektivitas belajar di kelas VI SDN Babadan. Dalam sebuah penelitian tentunya akan memperoleh manfaat. Sama halnya dengan penelitian ini, juga terdapat manfaat diantaranya Siswa lebih partisipatif dalam proses pembelajaran tolak peluru, menambah pengalaman dalam penggunaan media belajar yang di modifikasi, pengajaran tolak peluru menjadi lebih efektif serta menjadi inspirasi pengetahuan untuk menemukan media modifikasi yang lainya dalam cabang atletik dan cabang olah raga lainnya.

\section{METODE}

Subjek penelitian ini adalah siswa kelas VI Semester 1 SDN Babadan Kecamatan Bonang Kabupaten Demak, dengan jumlah siswa putri 14 orang dan putra 27 orang, jadi jumlah total 41 orang siswa. Sedangkan waktu dilaksanakan penelitian dimulai dari bulan Agustus s.d. November 2015.

Desain atau rancangan penelitian ini adalah Penelitian Tindakan Kelas. Prosedur atau langkah-langkah yang akan dilakukan dalam penelitian ini dilaksanakan dalam kegiatan yang berbentuk siklus penelitian. Setiap siklus penelitian terdiri dari empat kegiatan pokok yaitu, perencanaan, tindakan pelaksanaan, observasi, dan refleksi.

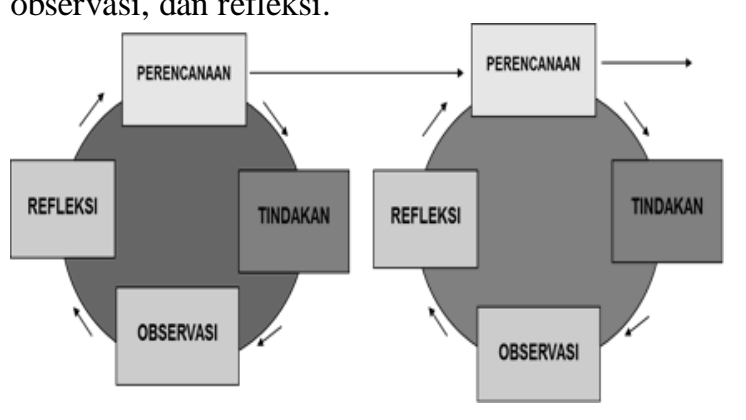

Gambar 1. Desain Penelitian Tindakan Model Kemmis \& Taggart

Teknik pengumpulan data dalam penelitian ini menggunakan beberapa cara: observasi, tes, angket, dan dokumentasi. Observasi digunakan untuk mengetahui secara langsung kondisi dilapangan baik saat praktik 
maupun dalam penggunaan media apakah sudah efektif atau belum. Tes digunakan untuk mengetahui sejauh mana keberhasilan proses pembelajaran yang diukur pada akhir kegiatan setiap. Tes dalam penelitian ini berupa praktik secara langsung penggunaan media yang telah disiapkan dan teknik dalam tolak peluru. Angket digunakan untuk mengetahui seberapa besar minat belajar siswa dalam mengikuti pembelajaran. Angket diedarkan pada siswa setiap akhir siklus. Dokumentesi merupakan suatu teknik pengumpulan data dengan menghimpun dan menganalisis dokumendokumen baik dokumen tertulis, gambar maupun elektronik.

\section{HASIL PENELITIAN DAN PEMBAHASAN Hasil Tindakan Prasiklus}

Sebelum melakukan tindakan peneliti mengadakan studi awal hingga memperoleh kondisi awal aktivitas siswa dalam belajar tolak peluru $50 \%$ aktif. Aktivitas guru dalam mengajar tolak peluru $76 \%$ aktif. Hasil belajar siswa awalan $\mathrm{Pa} 59 \%$ Pi $43 \%$ cukup efektif. Hasil belajar siswa cara menolak Pa $56 \% \mathrm{Pi}$ $43 \%$ cukup efektif. Hasil Belajar siswa sikap akhir pa $63 \%$ pi $36 \%$ kurang efektif.

\section{Hasil Tindakan Siklus I}

Hasil Tiap Aspek pada Tindakan Siklus 1antara lain aktivitas siswa dalam belajar tolak peluru $70 \%$ aktif. Aktivitas guru dalam mengajar tolak peluru 55\% cukup aktif. Hasil Belajar siswa awalan Pa 95\% Pi 70\%. Ada peningkatan, bagi yang belum bisa menuntaskan belajar diremedial. Respon siswa terhadap proses belajar tolak peluru $85 \%$ sangat puas

\section{Hasil Tindakan Siklus II}

Hasil yang diperoleh dalam tindakan siklus II antara lain aktivitas siswa dalam belajar Tolak Peluru $80 \%$ Aktif. Aktivitas guru dalam mengajar Tolak Peluru 100\% sangat aktif. Hasil Belajar siswa Pa 100\% Pi $79 \%$ efektif. Respon siswa terhadap proses belajar tolak peluru $85 \%$ sangat puas.

\section{Aktivitas Siswa dalam Belajar Tolak Peluru.}

Berdasarkan hasil observasi, aktivitas siswa pada siklus penelitian dengan dua siklus penelitian pada proses pembelajaran tolak peluru menunjukan adanya peningkatan aktivitas siswa dari siklus pertama sampai siklus kedua.
Berdasarkan hasil observasi aktivitas siswa pada dua siklus penelitian pada pembelajaran tolak peluru dengan peluru tiruan dari bola plastik menunjukkan adanya peningkatan aktivitas siswa dari siklus pertama sampai siklus kedua. Hasil yang diperoleh adalah siklus pertama aktivitas siswa mencapai $70 \%$, kemudian pada siklus kedua mencapai $80 \%$ ini berarti ada peningkatan $10 \%$ setelah ada treathment atau perbaikan pada siklus kedua, sehingga rata-rata keaktifan siswa selama dua siklus adalah $75 \%$. Mengacu pada indikator keaktifan siswa mencapai $75 \%$ memiliki kriteria aktif. Dengan kata lain, siswa selama mengikuti pembelajaran tolak peluru dengan media peluru tiruan dari bola plastik bergerak aktif baik saat mendapat tugas dari guru atau pun inisiatif sendiri.

2. Aktivitas Guru Dalam Mengajar Tolak Peluru

Berdasarkan hasil pengamatan oleh rekan guru aktivitas guru dalam mengajar tolak peluru dengan media peluru tiruan dari bola plastik mengalami kenaikan aktivitas. Aktivitas mengajar guru pada siklus pertama mencapai tingkat pencapaian $95 \%$, sedangkan pada siklus kedua setelah melakukan treatment pada proses pembelajaran, aktivitas guru mencapai $100 \%$. Ini berarti ada kenaikan aktivitas guru sebesar $5 \%$, sehingga rata-rata aktivitas guru pada dua siklus mencapai 97,5\%. Mengacu pada indikator aktivitas guru mencapai 97,5\% termasuk kriteria sangat aktif. Ini artinya guru dalam mengajar betul-betul sesuai dengan skenario pembelajaran atau RPP.

3. Hasil Belajar siswa

Berdasarkan hasil tes praktik yang dilakukan kepada siswa, dari mulai awalan, cara menolak, dan sikap akhir Tolak Peluru, pada akhir siklus ternyata mendapat kenaikan.

Pada siklus pertama hasil tes praktik awalan mencapai, putri $75 \%$, dan putra $95 \%$. Ini artinya, ada sebanyak 12 orang siswa putri yang mampu menuntaskan pembelajaran dari 14 orang, dan ada 26 orang siswa putra yang mampu menuntaskan pembelajaran dari 27 orang.

Masih pada siklus pertama, hasil tes praktik cara menolak mencapai, putri $80 \%$ dan putra $95 \%$. Ini artinya, ada sebanyak 11 orang putri yang mampu menuntaskan pembelajaran, dan 26 orang putra yang mampu menuntaskan pembelajaran.

Dari siklus pertama, hasil tes praktik sikap akhir mencapai $65 \%$ putri, dan $80 \%$ putra. Ini artinya ada 8 orang putri yang mampu 
menuntaskan pembelajaran, dan ada 26 orang putra yang mampu menuntaskan pembelajaran.

Pada siklus kedua ada peningkatan pada tes praktik tiap aspek. Pada tes praktik awalan mencapai $100 \%$ putra, dan $80 \%$ putri. Ini berarti bahwa ada 11 orang siswa yang mampu menuntaskan pembelajarannya, artinya untuk putra semua siswa mampu menuntaskan pembelajarannya, dan untuk putri ada 27 orang yang mampu menuntaskan pembelajarannya.

Pada tes praktik cara menolak terlihat mencapai $100 \%$ putra dan $80 \%$ putri. Ini berarti ada sebanyak 27 orang putra yang mampu menuntaskan pembelajaran, dan 11 orang siswa putri yang mampu menuntaskan pembelajaran.

Sementara pada tes praktik sikap akhir persentase mencapai $100 \%$ putra dan $80 \%$ untuk putri. Ini artinya bahwa ada 27 orang putra yang mampu menuntaskan pembelajaran, dan ada 11 orang putri yang mampu menuntaskan pembelajaran.

Aspek awalan pada siklus pertama mencapai $95 \%$ putra, dan $70 \%$ untuk putri, sedangkan pada siklus kedua putra mencapai $100 \%$ dan putri $80 \%$. Ada kenaikan 5\% untuk putra dan ada lonjakan kenaikan $10 \%$ untuk putri, dan rata-rata ketuntasan belajar untuk aspek Awalan mencapai 97,5\% putra dan putri mencapai $75 \%$. Mengacu pada indikator hasil belajar siswa menunjukan bahwa pembelajaran awalan pada tolak peluru dengan menggunakan media modifikasi bola plastik, berkategori sangat efektif untuk putra dan efektif untuk putri.

Aspek cara menolak pada siklus pertama mencapai $95 \%$ putra, dan $80 \%$ untuk putri, sedangkan pada siklus kedua putra mencapai $100 \%$ dan putri $80 \%$. Ada kenaikan 5\% untuk putra dan tidak ada kenaikan $0 \%$ untuk putri, dan rata-rata ketuntasan belajar untuk aspek Awalan mencapai $97,5 \%$ putra dan putri mencapai $80 \%$. Mengacu pada indikator hasil belajar siswa menunjukan bahwa pembelajaran cara menolak pada tolak peluru dengan menggunakan media modifikasi bola plastik, berkategori sangat efektif untuk putra dan sangat efektif untuk putri.

Aspek Sikap Akhir pada siklus pertama mencapai $95 \%$ putra, dan $60 \%$ untuk putri, sedangkan pada siklus kedua putra mencapai $100 \%$ dan putri $80 \%$. Ada kenaikan $5 \%$ untuk putra dan ada lonjakan kenaikan 20\% untuk putri, dan rata-rata ketuntasan belajar untuk aspek Awalan mencapai 97,5\% putra dan putri mencapai $80 \%$. Mengacu pada indikator hasil belajar siswa menunjukan bahwa pembelajaran sikap akhir pada tolak peluru dengan menggunakan media peluru tiruan dari bola plastik, berkategori sangat efektif untuk putra dan sangat efektif untuk putri.

4. Respon Siswa Terhadap Proses
Pembelajaran
Berdasarkan angket respon, yang disebarkan kepada siswa setelah selesai pelaksanaan pembelajaran siklus kedua, dapat dinyatakan bahwa pada umumnya siswa kelas VI bersikap positif terhadap proses pembelajaran tolak peluru dengan menggunakan media peluru tiruan dari bola plastik. Dalam pembelajaran siswa yang merasa senang dengan materi tolak peluru menggunakan media peluru tiruan dari bola plastik $85 \%$, sedangkan yang menyatakan biasa-biasa saja $10 \%$, dan merasa tidak senang 5\%. Kondisi ini berarti, bahwa sebagian besar siswa menikmati proses pembelajaran tolak peluru dengan media peluru tiruan dari bola plastik.

Dalam kaitannya dengan fungsi bola plastik sebagai pengganti peluru sesungguhnya ditanggapi positif oleh siswa, dengan pernyataan bahwa sebanyak $85 \%$ menyatakan bola plastik memudahkan dalam proses pembelajaran tolak peluru, sebanyak $10 \%$ menyatakan biasa-biasa saja, dan hanya sebesar $5 \%$ yang merasa disusahkan.

Lalu terkait dengan perintah atau tugastugas selama proses pembelajaran berlangsung, tanggapanya juga sebagian besar positif, yaitu $80 \%$ menyatakan mudah, $10 \%$ menyatakan biasa-biasa saja, dan yang menyatakan susah hanya sebesar $10 \%$.

Ketika dimintai tanggapan tentang kelanjutan pembelajaran tolak peluru dengan menggunakan media peluru tiruan dari bola plastik, sebagian besar siswa menyatakan bisa dilanjutkan $90 \%$, dengan alasan memudahkan belajar $80 \%$, dan selama peluru belum ada $10 \%$, sementara siswa yang menyatakan jangan diteruskan sebanyak 10\%, dengan alasan menyusahkan pembelajaran sebesar $2 \%$, dan sisanya $8 \%$ menyatakan harus segera diganti.

Mengacu pada Indikator Respon (Tingkat Kepuasan Belajar) Siswa, maka rata-rata tingkat respon siswa $85 \%$, mempunyai kriteria sangat puas. Kriteria ini menggambarkan bahwa siswa betul-betul merasa senang dan sangat menikmati pembelajaranya.

\section{SIMPULAN}

Penelitian Tindakan Kelas dengan judul Peningkatan Efektivitas Belajar Tolak Peluru Melalui Penggunaan Media Peluru Tiruan dari Bola Plastik Pada Siswa Kelas VI SDN 
Babadan Kecamatan Bonang Kabupaten Demak menghasilkan kesimpulan sebagai berikut:

1. Aktivitas siswa selama mengikuti proses pembelajaran Tolak peluru dengan menggunakan media peluru tiruan dari bola plastik di kategorikan sangat aktif. Dan setelah dilakukan siklus kedua, aktivitas siswa mengalami peningkatan keaktifan rata-rata sebesar $75 \%$. Kalau mengacu pada Indikator Keaktifan Siswa maka besaran keaktifan sebesar $75 \%$ termasuk kriteria Aktif.

2. Aktivitas mengajar guru pada siklus pertama mencapai tingkat pencapaian 95\%, sedangkan pada siklus kedua setelah melakukan treatment pada proses pembelajaran, aktivitas guru mencapai $100 \%$. Ini berarti ada kenaikan aktivitas guru sebesar 5\%, sehingga rata-rata aktivitas guru pada dua siklus mencapai 97,5\%. Mengacu pada Indikator Aktivitas Guru, besaran angka 97,5\% termasuk kriteria Sangat Aktif.

3. Rata-rata Ketuntasan Belajar untuk aspek Awalan mencapai 97,5\% putra dan putri mencapai $75 \%$. Mengacu pada Indikator Hasil Belajar Siswa pada Tabel 3.2, persentase tersebut menunjukan bahwa pembelajaran Awalan pada Tolak Peluru dengan menggunakan media peluru tiruan dari bola plastik, berkategori Sangat Efektif untuk putra dan efektif untuk putri. Rata-rata ketuntasan belajar untuk aspek Cara Menolak mencapai 97,5\% putra dan putri mencapai $80 \%$. Mengacu pada Indikator Hasil Belajar Siswa pada Tabel 3.2, persentase tersebut menunjukan bahwa pembelajaran Cara Menolak pada Tolak Peluru dengan menggunakan media modifikasi bola plastik, berkategori Sangat Efektif untuk putra dan Efektif untuk putri. Rata-rata Ketuntasan Belajar untuk aspek Sikap Akhir mencapai 97,5\% putra dan putri mencapai $70 \%$. Mengacu pada Indikator Hasil Belajar Siswa pada Tabel 3.2, persentase tersebut menunjukan bahwa pembelajaran Sikap Akhir pada Tolak Peluru dengan menggunakan media peluru tiruan bola plastik, berkategori
Sangat Efektif untuk putra dan Efektif untuk putri.

4. Respon siswa mengacu pada Indikator Respon Siswa, maka rata-rata tingkat respon siswa 85\%, mempunyai kriteria Sangat Puas.

\section{DAFTAR PUSTAKA}

Arikunto, Suharsimi. 1996. Pengelolaan Kelas dan Siswa. Jakarta: PT Raja Grafindo.

Arsyad, Azhar. 2009. Media Pembelajaran. Jakarta: PT. Raja Grafindo Persada.

Huda, Miftahul. 2014. Model-model Pengajaran dan Pembelajaran. Isu-isu Metodis dan Paradigmatis. Yogyakarta: Puspita Pelajar.

Karwati, Euis. Priansa, Donni Juni. 2013. Kinerja dan Profesionalisme Kepala Sekolah. Membangun Sekolah Bermutu. Bandung: Alfabeta.

Rivai, H. Veithzal. 2001. Faktor-Faktor yang Mempengaruhi Efektivitas Belajar Mahasiswa. Bandung: Pustaka Bani Quraisy.

Sadiman, Arief S. 1996. Media Pendidikan, Pengertian, Pengembangan, dan Pemanfaatannya. Jakarta: PT. Raja Grafindo Persada.

Sardiman A.M. 2011. Interaksi dan Motivasi Belajar Mengajar. Jakarta: Rajawali Pers.

Shoimin, Aris. 2014. 68 Model Pembelajaran Inovatif dalam Kurikulum 2013. Yogyakarta: Ar-ruzz Media.

Suparman, Atwi. 1997. Desain Instruksional. Jakarta: PAU PPAI UT.

Surya, Mohamad. 2004. Psikologi Pembelajaran \& Pengajaran. Bandung: Alfabeta.

Sudrajat, Akhmad. 2008. Perngertian, Fungsi, dan Media Pembelajaran. Artikel online 
https://akhmadsudrajat.wordpress.com/ 2008/01/12/konsep-media-

pembelajaran/. 